\title{
Suspension and Effervescent Granules for Oral Suspension Dosage Form
}

National Cancer Institute

\section{Source}

National Cancer Institute. Suspension and Effervescent Granules for Oral Suspension

Dosage Form. NCI Thesaurus. Code C149962.

Suspension and effervescent granules, both containing active ing redients, intended for the preparation of an oral suspension by dissolving or dispersing the granules in the suspension. 